\title{
Antioksidativni sinergizam cijeđenog soka aronije i mješavine crnog vina triju sorti grožđa s područja Bujštine
}

\section{Antioxidative synergism of the squeezed aronia juice and red wine mixtures of three grape varieties from the Bujština area}

\author{
Ela Mijatović ${ }^{*}$, Dalibor Broznić ${ }^{2}$
}

${ }^{1}$ Sveučilište u Rijeci, Medicinski fakultet, Rijeka, Hrvatska

${ }^{2}$ Zavod za medicinsku kemiju, biokemiju i kliničku kemiju, Sveučilište u Rijeci, Medicinski fakultet, Rijeka, Hrvatska

\section{*Dopisni autor:}

Ela Mijatović, univ. bacc. sanit. ing. Sveučilište u Rijeci, Medicinski fakultet Braće Branchetta 20, 51000 Rijeka, Hrvatska E-mail: ela.mijatovic26@gmail.com
Sažetak. Cilj: Utvrditi mogući sinergizam antioksidansa iz prirodnih uzoraka soka aronije i crnog vina te ispitati kinetiku reakcija između DPPH radikala i antioksidansa prisutnih u uzorcima. Materijali i metode: Antioksidativna aktivnost u pet metanolnih uzoraka (ARONIJA, VINO, MIX 1 (50\% soka aronije i $50 \%$ crnog vina), MIX 2 (75\% soka aronije i $25 \%$ crnog vina), MIX 3 ( $25 \%$ soka aronije i $75 \%$ crnog vina)) određena je pomoću DPPH` i TEAC testova i analizirana spektrofotometrijski, dok se kinetika kemijskih reakcija pratila trima monofaznim i jednim bifaznim matematičkim modelom. Rezultati: Prema kvantifikaciji TEAC testa, najjači antioksidacijski kapacitet smjesa, a ujedno i najbolji sinergizam antioksidansa, pokazuje MIX 1 (75 mmol/kg), zatim MIX 3 i MIX 2 (67 i 62 mmol/kg). Gubitak signala DPPH radikala najjači je u uzorku ARONIJA (81\%), dok je najslabiji u uzorku VINO (21\%). Kombinacijom napitaka, kemijske reakcije $s$ radikalom odvijaju se dvjema vrstama antioksidansa čiji se mehanizam djelovanja odvija u dvjema fazama brzine kemijske reakcije. Zaključak: Dodatak soka aronije u crno vino uzrokuje porast njegove antioksidativne aktivnosti. Odnosno, ukoliko se priprema smjesa aronijinog soka i crnog vina, komponente moraju biti u jednakim udjelima (50:50) kako bi se postigao što bolji sinergizam ovih dviju vrsta antioksidansa, a time i ostvario jači zdravstveni učinak.

Ključne riječi: antioksidansi; aronija; DPPH radikal; kinetika; TEAC test; vino

Abstract. Aim: To determine the synergism of antioxidants from natural samples of chokeberry juice and red wine as well as to examine the reaction kinetics between DPPH radical and antioxidants presented in the samples. Materials and Methods: Antioxidant activity in five methanolic samples (ARONIJA, VINO, MIX 1 (50\% chokeberry juice and 50\% red wine), MIX 2 ( $75 \%$ chokeberry juice and $25 \%$ red wine), MIX 3 ( $25 \%$ chokeberry juice and $75 \%$ red wine)) was measured spectrophotometrically using DPPH ${ }^{\circ}$ and TEAC assays, while the chemical reaction of kinetics was analyzed with three monophasic and one biphasic mathematical models. Results: TEAC test shows the best antioxidants synergism of, as well as the strongest antioxidant capacity for mixture, MIX $1(75 \mathrm{mmol} / \mathrm{kg})$, followed by MIX 3 and MIX 2 (67 and $62 \mathrm{mmol} / \mathrm{kg}$ ). The inhibition of DPPH radical signal was the strongest in the ARONIJA sample (81\%), while it was the weakest in the VINO sample (21\%). By combining beverages, two different types of antioxidants inhibited the DPPH radical causing two phases of reaction with different chemical reaction rates. Conclusion: The addition of chokeberry juice to red wine causes an increase in its antioxidant activity. Furthermore, if the chokeberry juice and red wine mixture is prepared, the samples should be in equal amount (50:50) in order to achieve the best antioxidants synergism and also strengthened the health effect.

Key words: antioxidants; chokeberry; DPPH radical; kinetics; TEAC assay; wine 


\section{UVOD}

Zdrava hrana ima sve veću ulogu u prehrani populacije. Različite varijacije u pripremi obroka, sinergizmi namirnica poput voća i povrća ponekad mogu ometati pojedinačnu učinkovitost. $U$ tom slučaju, poznavanje kemijske pozadine hrane važno je zbog izbjegavanja nepoželjnih mješavina. Sok aronije i crno vino idealni su napitci za pripremu smjesa zbog zajedničkih karakteristika. Osim što su dobiveni od plodova, prepoznatljivi su po svojim sličnim pigmentacijama, antioksidansima te po svom djelovanju u istim organskim sustavima.

Aronija je ljekovita biljka koja pripada porodici ruža Rosaceae te se danas sve više koristi u proizvodnji sokova, čajeva, džemova i kao prirodno bojilo hrane ${ }^{1}$. Zbog visokog udjela polifenola u svome sastavu pokazuje izrazito antioksidativno djelovanje ${ }^{2}$, dok antocijaninima i niacinom ostvaruje svoju kardioprotektivnu ulogu direktnim poboljšanjem krvožilnih aktivnosti uslijed smanjenja kolesterola, antiagregacije i krvnog tlaka ${ }^{3}$. Studije su predstavile i A tip proantocijanidina koji djeluje antiadhezijski i time sprječava vezanje $S$. epidermiditis i uropatogene $E$. coli na površinama katetera i leća ${ }^{4}$. U središnjem živčanom sustavu aronija potiče kognitivne moždane funkcije centralnog kolinergičnog sustava (engl. central cholinergic system; CCS) koji regulira acetilkolin čije je smanjeno izlučivanje primijećeno kod starijih osoba i pacijenata s dijagnosticiranom Alzheimerovom bolesti ${ }^{5}$. Za vrijeme kemoterapija ovaj jaki antioksidans uspijeva potaknuti sintezu antioksidativnih enzima poput superoksid dismutaze, glutation peroksidaze $\mathrm{i}$ glutation reduktaze $u$ $\mathrm{krvi}^{6}$. Uz aroniju, po svom antioksidacijskom djelovanju poznato je također i crno vino. lako su kolijevke njegovog uzgoja Italija i Francuska, u Sredozemlju se ističe i Hrvatska, čije se autohtone vrste crnog vina uzgajaju na plodnom sjeverozapadnom području Istre u kojem se izdvaja lokacija Bujštine: Brtonigla, Buje i Oprtalj. U kemijskom sastavu crnog vina, osim vode, alkohola, organskih kiselina i šećera, nalaze se i tanini, katehini, terpeni, flavonoidi, merkaptani, esteri i antocijanini koji, uslijed konzumacije, pospješuju cirkulaciju u tijelu. Nakon što povećaju sistolički i dijastolički tlak, smanjuju unutarnje srčane i ventrikularne polarizacijske intervale. Time se zaobi- lazi rizik od ishemičnog miokarda, kardiopatije i, općenito, smrti ${ }^{7,8}$. Uočeno je da dnevna konzumacija (do $3 \mathrm{dL}$ ) sprječava inflamacije, bolesti koronarnih žila i rizik od ateroskleroze ${ }^{9}$. Polifenoli, kao dijelovi kemijskog sastava, oslobađaju hidroksilne radikale koji produciraju $\mathrm{H}_{2} \mathrm{O}_{2}$ i time oštećuju bakterijski DNA, remete strukturu stanične membrane i uzrokuju poremećaj u izmjeni iona bakterija roda Streptococcus i subgingivalnih biofilmova peridontalnih patogena poput $P$. gingivalis, $A$. actinomycetemcomitans i $F$. nucleatum ${ }^{10}$.

Zbog visokog udjela polifenola, aronija pokazuje izrazito antioksidativno djelovanje, dok antocijaninima i niacinom ostvaruje svoju kardioprotektivnu ulogu direktnim poboljšanjem krvožilnih aktivnosti uslijed smanjenja kolesterola, antiagregacije i krvnog tlaka. Crno vino, nakon što poveća sistolički i dijastolički tlak, smanjuje unutarnje srčane i ventrikularne polarizacijske intervale te rizik od ishemičnog miokarda i kardiopatije.

No, kada je riječ o borbi protiv brojnih karcinoma, ističu se flavonoidi koji sprječavaju proliferaciju i nekontrolirano dijeljenje tumorskih stanica kod renalnog, gastrointestinalnog i plućnog karcinoma te kod karcinoma dojke i prostate ${ }^{11}$.

Osim u imunološkom, spomenuti spojevi obavljaju svoje zadaće i u živčanom sustavu u obliku poboljšanja kognitivne sposobnosti, reduciranja neuroinflamacija te oksidativnog stresa. Navedene patogeneze najčešće su rezultat neravnoteža između oksidansa i antioksidansa, zbog pretjerane proizvodnje i smanjenog uklanjanja reaktivnih kisikovih vrsta (engl. reactive oxygen species; ROS) u organizmu $^{12}$. Riječ je o složenim kemijskim reakcijama, do čijeg se mehanizma i kinetike može doći matematičkim modelima koji zahtijevaju unos rezultata mjerenja dobivenih analitičkim metodama.

Provedeno istraživanje temeljilo se na određivanju mogućeg sinergizma antioksidansa iz prirodnih uzoraka soka aronije i crnog vina. Mjerenjem antioksidacijskih kapaciteta, a time i redukcije signala DPPH antioksidansima u soku aronije, crnom vinu, kao i u njihovim smjesama, nastojali su se odrediti i kinetički parametri ne bi li se dobile detaljnije informacije o mehanizmima uključenim u reakcije između antioksidansa i radikala. 


\section{MATERIJALI I METODE}

\section{Kemikalije}

U pripremi uzoraka korišten je metanol (J.T. Baker, Deventer, Nizozemska) kromatografske čistoće, dok su u provedbi testova antioksidacijskih kapaciteta primijenjeni reagensi proizvođača Sigma-Aldrich (Taufkirchen, Njemačka): 2,2-Diphenyl-1-picrylhidrazyl (DPPH radikal) i ( \pm )-6-Hydroxy-2,5,7,8-tetramethylchromane-2-carboxylic-acid (TROLOX).

\section{Uzorci aronije i crnog vina}

Kao ishodišni uzorci korišteni su: 100-postotni cijeđeni sok aronije proizvođača „OPG DEVALD IGOR" Bilje, Hrvatska, kupljen na tržnici grada Umaga i domaće crno vino proizvedeno od sorti grožđa terana, refoška s crvenom peteljkom i crnog vranca s lokaliteta Bujštine.

\section{Priprema uzoraka za DPPH` analizu}

Za $\mathrm{DPPH}^{\bullet}$ analizu pripremljeno je pet metanolnih uzoraka: ARONIJA (100-postotni aronijin sok), VINO (100-postotno crno vino), MIX 1 (50\% soka aronije i $50 \%$ crnog vina), MIX 2 (75 \% soka aronije i $25 \%$ crnog vina), MIX 3 (25\% soka aronije i $75 \%$ crnog vina). Metanolni uzorci ARONIJE i VINA pripremljeni su razrjeđivanjem $10 \mu \mathrm{L}$ nativnih otopina $s$ metanolom kako bi se dobila 0,1-postotna otopina, dok su uzorci MIX 1 - MIX 3 pripremljeni miješanjem različitih volumnih udjela ishodišnih otopina ARONIJE i VINA te razrjeđivani metanolom.

\section{Primjena DPPH` testa za određivanja antioksidativne aktivnosti uzoraka}

Antioksidativna aktivnost, redukcija signala radikala u reakciji s antioksidansima uzoraka, određena je $\mathrm{DPPH}^{\bullet}$ testom prema metodi koju su uveli Brand-Williams i suradnici ${ }^{13}$. Na početku analize pripremljena je slijepa proba te uzorci koji se dobivaju miješanjem otopina uzoraka i metanola u omjerima 1 : 3 (V/V). Nastalim smjesama potom su mjerene apsorbancije spektrofotometrom UVVIS Spectroquant ${ }^{\circledR}$ Pharo 100 (Merck, Darmstadt, Njemačka) na 515 nm u vremenskim intervalima od jedne minute. Postotak gubitka DPPH` signala izračunat je sljedećom jednadžbom (1):

$\mathrm{DPPH}^{*}$ inhibicija $=\frac{A_{\text {kontrola }-} A_{\text {uzorka }}}{A_{\text {uzorka }}} \cdot 100$ gdje su:

$A_{\text {kontrola }}$ i $A_{\text {uzorak }}$ izmjerene apsorbancije kontrolne otopine DPPH radikala i metanola bez uzorka pri $\mathrm{t}=0 \mathrm{i}$ otopina uzoraka pri $\mathrm{t} \leq 60 \mathrm{~min}$.

\section{Primjena TEAC testa za određivanja antioksidacijskog kapaciteta uzoraka}

Antioksidacijski kapacitet određen je TEAC testom i izražen Trolox ekvivalentom. Korišteni Trolox standard ili hidrosolubilni analog vitamina $\mathrm{E}$ razrijedio se na pet otopina koncentracija od 0,00; 0,03; 0,06; 0,09 i-0,012 mM, a nakon miješanja s DPPH radikalom ( $1: 3 ; \mathrm{V} / \mathrm{V})$, izmjerene su apsorbancije dobivenih smjesa na $515 \mathrm{~nm}$. Dobiveni postotak gubitka signala DPPH radikala $u$ Trolox otopinama poslužio je za kvantifikaciju antioksidativne aktivnosti uzoraka čija je vrijednost izražena u $\mathrm{mmol} / \mathrm{kg}$ te je izračunat sljedećom jednadžbom (2):

$\left(\frac{n(\mathrm{TE})}{m \text { (aronije } / \text { vina })}\right)=\frac{c(\mathrm{TE}) \cdot V_{\text {otopine }} \cdot 1000}{m \text { (aronije } / \text { vina })}$

Prema jednadžbi, $c(T E)$ predstavlja koncentraciju Troloxa iz baždarenog pravca koja je ekvivalentna postotku inhibicije DPPH radikala u otopinama uzoraka, dok je $V_{\text {otopine }}$ ukupni volumen $(10 \mathrm{~mL}) \mathrm{i}$ $m$ masa (g) uzoraka.

\section{Kinetička analiza inhibicije signala DPPH radikala pomoću matematičkih modela}

Kako bi se detaljnije proučio mehanizam nestajanja DPPH radikala u reakcijama, primijenjeni su sljedeći matematički modeli:

1) kinetički model nultog reda

$\mathrm{DPPH}_{t}^{\bullet}=\mathrm{DPPH}_{0}^{\circ}+\mathrm{k}_{0} \times \mathrm{t}$

2) kinetički model prvog reda

$\mathrm{DPPH}_{t}^{\cdot}=\mathrm{DPPH}_{0}^{\cdot} \times \mathrm{e}^{-\mathrm{k}_{1} \times \mathrm{t}}$

3) logaritamski kinetički model

$\mathrm{DPPH}_{t}^{\cdot}=\mathrm{DPPH}_{0}^{\cdot} \times \mathrm{e}^{-\mathrm{k}_{1} \times \mathrm{t}}+\mathrm{c}$

4) bifazni kinetički model prvog reda

$\mathrm{DPPH}_{t}^{\bullet}=\mathrm{DPPH}_{1}^{\bullet} \times \mathrm{e}^{-\mathrm{k}_{1} \times \mathrm{t}}+\mathrm{DPPH}_{2}^{\bullet} \times \mathrm{e}^{-\mathrm{k}_{1} \times \mathrm{t}}+\mathrm{DPPH}_{r}^{\bullet}(6)$

$U$ formulama $\mathrm{DPPH}_{0}^{\circ}, \mathrm{DPPH}_{t^{\prime}}, \mathrm{DPPH}_{1}^{\circ}, \mathrm{DPPH}_{2}^{\circ}$, $\mathrm{DPPH}_{r}^{\bullet}$ predstavljaju količinu radikala na početku eksperimenta, u vremenu $t$, u prvoj i drugoj fazi reakcije gdje je $t=0$ i preostalu količinu radikala na kraju kemijske reakcije čije su konstante brzine $k_{0}, k_{1}$ i $k_{2}$ i vrijeme $t$. 


\section{Statistička analiza podataka}

Analize antioksidativne aktivnosti provedene su na način da su od svakoga uzorka pripremljena dva poduzorka te su oni analizirani u duplikatu. Rezultati izraženi kao medijan s minimalnom i maksimalnom vrijednošću, statistički su obrađeni softverom Statistica ${ }^{\circ}$ v. $13.0^{24}$, gdje su se ispitivale razlike među uzorcima neparametrijskim MannWhitney $U$ testom na razini značajnosti $P<0,05$ zbog malog broja uzoraka obuhvaćenih analizom. Matematički modeli kinetike analizirani su u računalnom programu Wolfram Research Matematica 9 (WolframResearch Co, SAD), a za određivanje podudaranosti modelnih rezultata i eksperimentalnih mjerenja koristili su se Pearsonov koeficijent korelacije $\left(R^{2}\right)$, standardna pogreška modela (engl. Scaled Root Mean Squared Error; SRMSE) i pogreška hi-kvadrat testa ( $\chi^{2}$ test pogreška $(\%)$ ).

\section{REZULTATI}

\section{Antioksidativna aktivnost uzoraka dobivena DPPH` testom}

Prema grafičkom prikazu (Slika 1) koji obuhvaća cjelokupno vrijeme reakcije svakog uzorka s radikalom, najjaču antioksidativnu aktivnost pokazao je uzorak ARONIJA, a najslabiju uzorak VINO. U prvoj minuti gubitak signala radikala za ARONIJU iznosio je $22 \%$, dok je u 60 . minuti rastao iznad $81 \%$. Uzorak VINO u prvoj minuti pokazao je gubitak signala od $14 \%$, s nepromijenjenom apsorbancijom nakon desete minute i gubitkom od $21 \%$.

$\mathrm{U}$ prvih deset minuta reakcije svi su uzorci pokazali pojačanu inhibiciju signala radikala, pri čemu je od mješavina uzoraka najjaču antioksidativnu aktivnost predstavljao uzorak MIX 1, a slijedili su ga MIX 2 i MIX 3. Na kraju ispitivanog perioda inhibicija radikala za sve tri mješavine bila je približno ista i iznosila je $\approx 53 \%$.

\section{Antioksidativni kapacitet uzoraka dobiven TEAC testom}

Koncentracija TEAC za uzorak ARONIJA iznosila je $100 \mathrm{mmol} / \mathrm{kg}$, a za uzorak VINO $30 \mathrm{mmol} / \mathrm{kg}$. Kao i kod DPPH ${ }^{\bullet}$ metode, spomenuti uzorci predstavljali su najveću i najmanju antioksidativnu aktivnost. Za MIX 1 TEAC iznosio je $76 \mathrm{mmol} / \mathrm{kg}$, a odmah nakon slijedili su MIX 3 i MIX 2 s vrijednostima od $68 \mathrm{mmol} / \mathrm{kg}$ i $62 \mathrm{mmol} / \mathrm{kg}$. Odnosno, najveći antioksidativni kapacitet pokazao je, poslije ARONIJE, MIX 1 pa potom MIX 3 i MIX 2 (Slika 2). Razlike u navedenim TEAC rezultatima

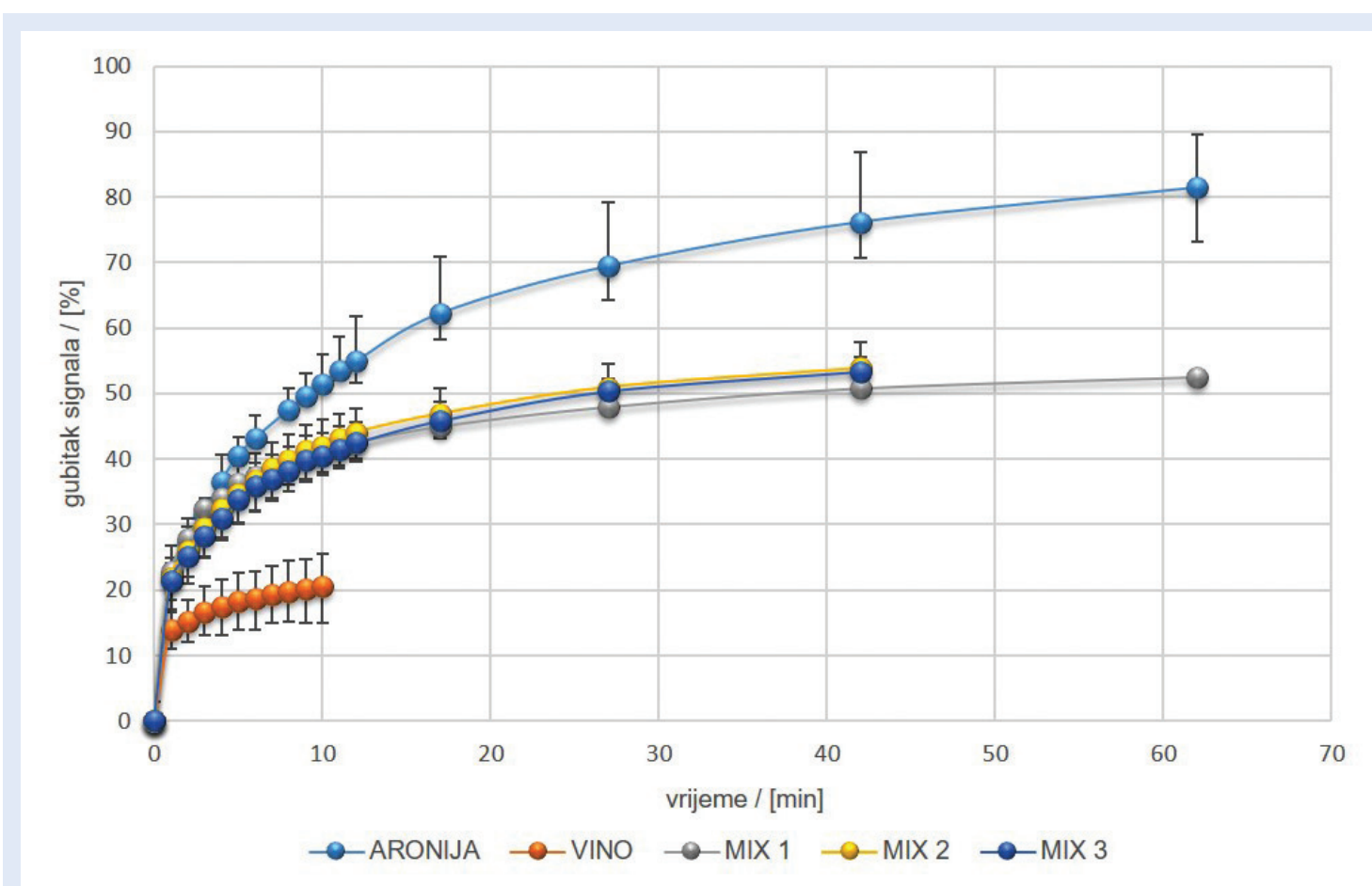

Slika 1. Gubitak signala DPPH radikala u uzorcima ARONIJA, VINO, MIX 1, MIX 2 i MIX 3 tijekom cijelog vremena reakcija. Rezultati su prikazani kao medijan s minimalnom i maksimalnom vrijednosti $(N=4)$. 


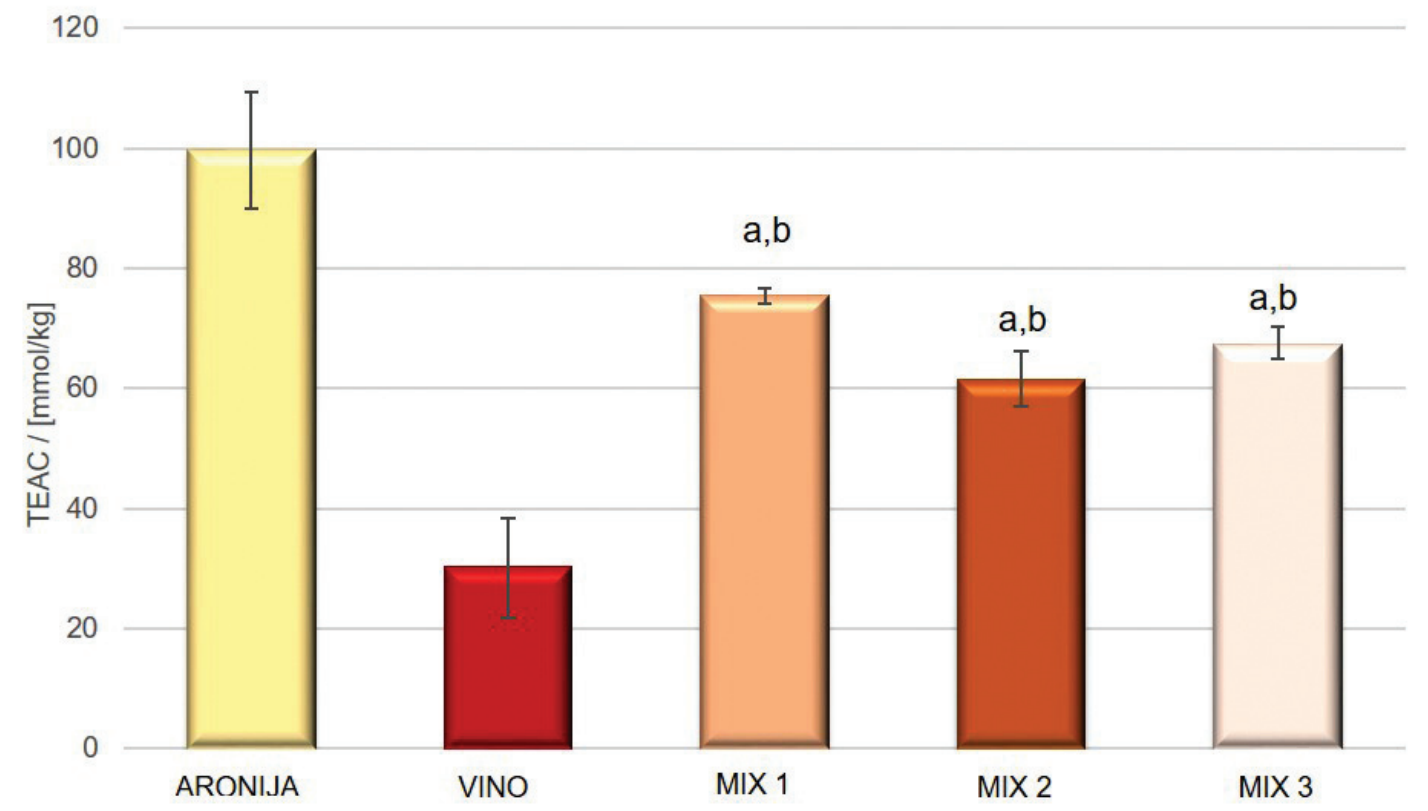

Slika 2. Antioksidativni kapacitet uzoraka prikazan TEAC testom. Rezultati su izraženi kao medijan s minimalnom i maksimalnom vrijednosti ( $N=4)$ TEAC (mmol/kg uzorka).

Statistički značajne razlike $(P<0,05)$ između analiziranih skupina uzoraka prikazane su malim tiskanim slovima: a - ARONIJA i ostali uzorci, $b$ - VINO i ostali uzorci.

testirane su statistički te je utvrđeno da postoji statistički značajna razlika antioksidativne aktivnosti između uzoraka ARONIJA i preostalih uzoraka $(P<0,05)$ te između uzoraka VINA i otopina MIX1 - MIX3 $(P<0,05)$.

\section{Rezultati kinetike nestajanja DPPH radikala u reakciji s antioksidansima uzoraka}

Na temelju usporedbe statističkih pokazatelja koji predstavljaju podudaranje eksperimentalnih i modelnih podataka, bifazni model kinetike prvog

Tablica 1. Kinetički i statistički parametri dobiveni u analizi matematičkih modela nultog i bifaznog modela kinetike prvog reda za uzorke ARONIJA, VINO, MIX 1, MIX 2 i MIX 3.

\begin{tabular}{|c|c|c|c|c|c|}
\hline \multirow{2}{*}{ Model/parametar } & \multicolumn{5}{|c|}{ Uzorci soka aronije i crnog vina } \\
\hline & ARONIJA & VINO & MIX 1 & MIX 2 & MIX 3 \\
\hline \multicolumn{6}{|l|}{ Model kinetike nultog reda } \\
\hline$k_{0}$ & $-1,0210$ & $-1,3190$ & $-0,4898$ & $-0,8812$ & $-0,8951$ \\
\hline$R^{2}$ & 0,9592 & 0,9982 & 0,9799 & 0,9820 & 0,9855 \\
\hline SRMSE & 0,2155 & 0,0415 & 0,1423 & 0,1340 & 0,1207 \\
\hline$\chi^{2}$-pogreška (\%) & 17,70 & 3,35 & 11,70 & 10,50 & 9,93 \\
\hline \multicolumn{6}{|l|}{ Bifazni model kinetike prvog reda } \\
\hline$k_{1}$ & 2,3790 & $-0,0144$ & 0,7555 & 1,2500 & 1,9510 \\
\hline$k_{2}$ & 0,5091 & $-0,0148$ & 0,6074 & 0,9888 & 0,0970 \\
\hline $\mathrm{DPPH}_{r}^{\bullet}(\%)$ & 19,88 & 170,70 & 47,91 & 46,83 & 47,59 \\
\hline$R^{2}$ & 0,9985 & 0,9981 & 0,9994 & 0,9999 & 0,9999 \\
\hline SRMSE & 0,0188 & 0,0415 & 0,0101 & 0,0083 & 0,0078 \\
\hline$\chi^{2}$-pogreška (\%) & 1,70 & 3,88 & 0,91 & 0,75 & 0,70 \\
\hline
\end{tabular}

$k_{\sigma^{\prime}} k_{1}, k_{2}$ - konstante brzine kemijske reakcije; $R^{2}$ - Pearsonov koeficijent korelacije; SRMSE - standardna pogreška modela (engl. „SSaled Root Mean Squared Error"); $\chi^{2}$ pogreška - hi-kvadrat test; $\mathrm{DPPH}_{r}^{*}$ - neizreagirani $\mathrm{DPPH}^{\bullet}$ radikal bifaznog modela kinetike prvog reda. 


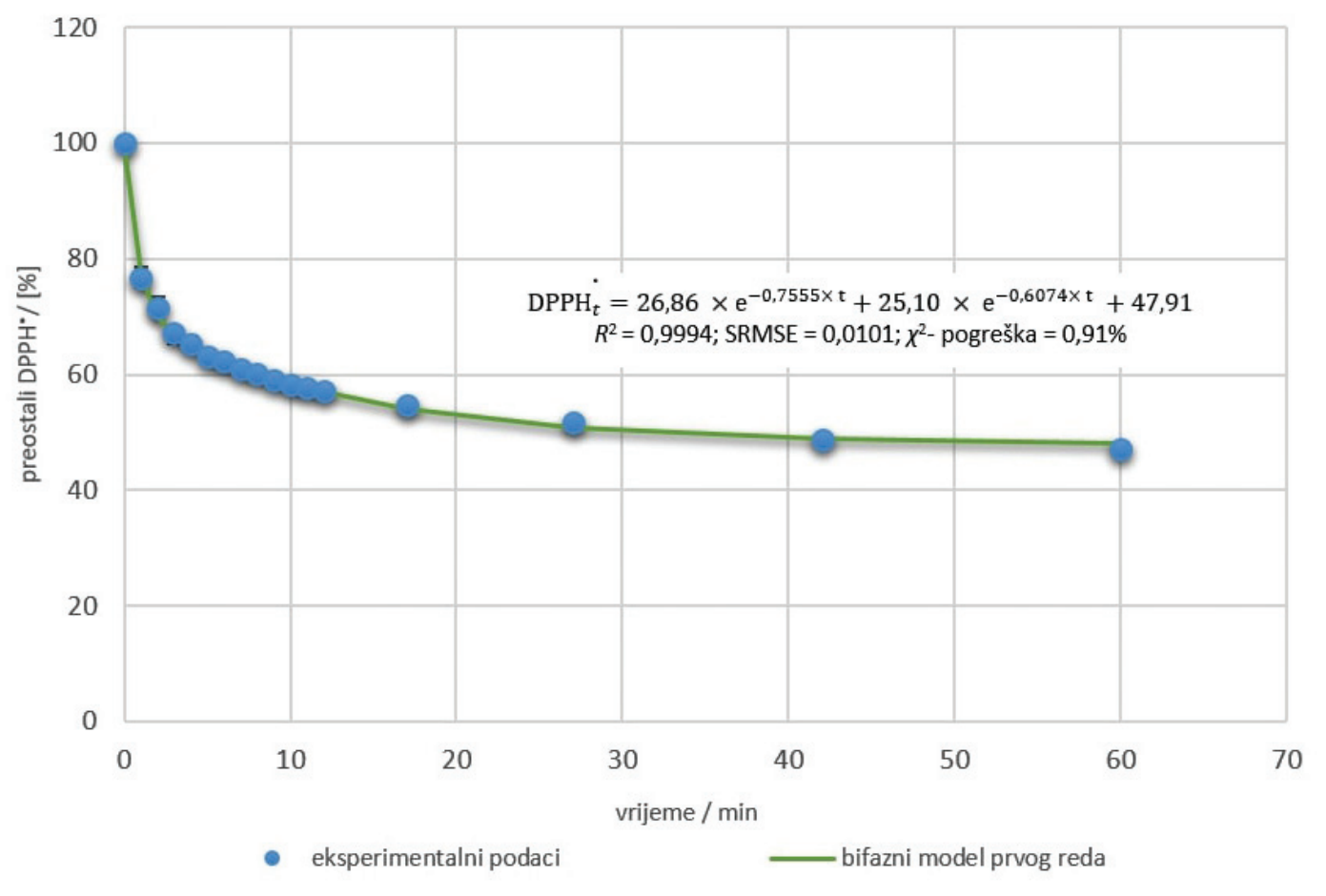

Slika 3. Grafički prikaz ovisnosti eksperimentalnih podataka i teorijskih vrijednosti dobivenih matematičkim modelima za reakciju nestajanja DPPH radikala u uzorku MIX 1.

Na slici: EXP - eksperimentalni podatci, BMPR - teorijski podatci dobiveni najboljom kinetikom bifaznog modela prvog reda. Rezultati su prikazani kao medijan s minimalnom i maksimalnom vrijednosti $(\mathrm{N}=4)$.

reda prikazao je najbolji opis reakcija radikala i uzoraka, dok je model kinetike nultog reda bio odgovoran za najlošiji prikaz kinetike (Tablica 1 ). Budući da je TEAC test pokazao da je mješavina aronije i vina MIX 1 imala najjače antioksidativno djelovanje te je ona odabrana za detaljnije objašnjenje kinetičke reakcije između DPPH radikala i antioksidansa prisutnih u mješavini.

\section{Statistički pokazatelji i kinetički parametri} najbolje i najlošije opisane kinetike uzorka MIX 1

Bifazni model prvog reda za uzorak MIX 1 prikazao je najveći koeficijent determinacije $\left(R^{2}=\right.$ 0,9994), a najmanji SRMSE $(0,0101)$ i najmanju $\chi^{2}$-pogrešku $(0,91 \%)$ (Tablica 1$)$. Koeficijent determinacije $R^{2}$ modela nultog reda za uzorak MIX 1 dobiven je u vrijednostima od 0,9799, dok su SRMSE $(0,1423)$ i $\chi^{2}$ - pogreška $(11,70 \%)$ bili najvećih iznosa u odnosu na ostale uzorke. U bifaznom modelu prvog reda dobivene su vrijednosti dviju konstanti kinetike $\left(k_{1}, k_{2}\right)$ za prvu i drugu fazu kemijske reakcije. Konstante, odnosno brzine kemijskih reakcija, veće su u prvoj nego u dru- goj fazi reakcije, što potvrđuje prisutnost „brzih“ i „sporih“ antioksidansa. U prvom susretu radikala i antioksidansa vrijednost konstante za MIX 1 iznosila je 0,7555, dok je u drugom dijelu kemijske reakcije rezultat konstante pao na 0,0970. Promatrajući preostalu količinu radikala na kraju kemijske reakcije DPPH• kao krajnju točku grafičkog prikaza (Slika 3), uočena je druga po redu preostala količina radikala od $47,15 \%$ za uzorak MIX 1.

\section{RASPRAVA}

$\mathrm{Na}$ osnovi teorijskog znanja, analizirani uzorci soka aronije, crnog vina i njihovih mješavina sadrže visoke udjele polifenola u svom kemijskom sastavu. Interakcije između polifenola različitih i istovrsnih komponenti mogu dovesti do promjena u antioksidacijskom kapacitetu uzoraka.

Upravo takvi odnosi uzrokuju sinergistički, antagonistički ili adicijski efekt. Pojedine studije pokazale su sinergistički porast antioksidativne aktivnosti u reakciji između soka aronije i $\alpha$-tokoferola, a za crno vino potvrdile su sinergističku ovisnost 
vlastitih polifenola te aditivni efekt u slučaju mješavina ${ }^{14}$. Prema istraživanju Pinela i suradnika ${ }^{15}$, dokazano je kako katehini, resveratrol i kvercetin pokazuju negativnu sinergističku interakciju (pad antioksidacijskog kapaciteta), dok su Hidalgo i suradnici $^{16}$ proučavali antioksidativnu aktivnost 11 flavonoidnih molekula, koristeći DPPH radikal za testiranje flavonoid-flavonoid interakcija te njihovih utjecaja na ukupnu antioksidativnu aktivnost. $\mathrm{U}$ istraživanju su pronađene različite kombinacije flavonoida koje pokazuju nisku inhibiciju DPPH

Radi jače antioksidativne aktivnosti, u bifaznu kinetiku antioksidansi soka aronije uvode i antioksidanse crnog vina. Pod njihovim utjecajem, „brzi“ i „spori“ antioksidansi crnog vina raspodjeljuju se između „brzih“ i „sporih" antioksidansa soka aronije koji time uzrokuju porast antioksidativne aktivnosti crnog vina.

radikala ili antagonistički efekt. Takve varijacije nazvali su i kopigmentacijskim reakcijama u kojima antocijanini mogu reagirati s ostalim molekulama (kopigmentima) flavonoida, metala i organskih kiselina uz stvaranje kompleksnijih molekula. Navedene formacije najčešće dovode do polimerizacijskih reakcija koje remete primarnu antioksidativnu aktivnost te mogućnost hidrokslinih skupina antioksidansa u redukciji slobodnih radikala. Postoji mogućnost stvaranja i vodikovih veza između fenolnih komponenti koje jednako ometaju hidroksilnu skupinu i time uzrokuju pad antioksidativne aktivnosti. Ovakve pojave češće se javljaju u koncentriranijim smjesama nego u jednostavnijima kod kojih se ne ometa učinkovitost pojedinačnih molekula antioksidansa u reakciji sa slobodnim radikalom. U ovom istraživanju uzorak sa 100-postotnim aronijinim sokom pokazivao je najveći antioksidacijski kapacitet u obama testovima (DPPH• i TEAC). Međutim, različite smjese soka aronije i crnog vina pokazale su niže antioksidativne aktivnosti, pri čemu se potvrđuje antagonizam aronije u mješavini s crnim vinom. $\mathrm{U}$ istraživanju Tolić i suradnika ${ }^{17}$ ispitivao se antioksidacijski kapacitet 11 sokova aronije različitih proizvođača i država podrijetla, ali istog udjela aronije u soku (100\%). Rezultati, inhibicije signala DPPH radikala, izraženi su u mmol TE/kg i pre- ma kojima najveći antioksidacijski kapacitet pokazuje uzorak „Voelkel GmbH“, Njemačka, s vrijednostima od 40,2 mmol TE/kg. Promatrajući rezultat najveće antioksidativne aktivnosti ovog istraživanja (100 mmol TE/kg za sok aronije), prethodno spomenuti rezultat 2,5 puta je manjih vrijednosti. Razlog tome je vjerojatno različita priprema uzoraka, valna duljina mjerenja (517 $\mathrm{nm})$, različito vrijeme analize i geografsko podrijetlo aronije, kao i različiti klimatski uvjeti uzgoja te ekstrakcijske metode u dobivanju soka. Osim navedenog, u istraživanju je istaknuto kako pasterizacija i skladištenje imaju isto bitnu ulogu u antioksidativnoj aktivnosti sokova aronije. Najveći utjecaj posebno imaju reakcije oksidacije za vrijeme procesa pasterizacije i temperatura skladištenja. Stratil i suradnici ${ }^{18}$ određivali su antioksidativnu aktivnost 29 vrsta vina spektrofotometrijskim metodama. Crna vina činila su 21 uzorak, a proizvedena su u Češkoj Republici ili uvezena iz drugih država. Najveće Trolox vrijednosti crnih vina, odnosno antioksidacijski kapacitet, pokazali su jedno vino iz Italije i dva vina, Cabernet Sauvignon i Syrah, iz Argentine s vrijednostima TE od 34,3 do $34,7 \mathrm{mmol} / \mathrm{kg}$. Dobiveni rezultati gotovo se podudaraju s rezultatom antioksidacijskog kapaciteta (30 mmol/kg) crnog vina ovog istraživanja. Za male varijacije u rezultatima odgovorne su različite sorte grožđa, izloženost suncu, berbe grožđa te procedure u proizvodnji vina. Bifazna kinetika modela prvog reda uočena je i u prijašnjim studijama koje su uključivale uzorke aronije. Jakobek i suradnici ${ }^{19}$ bavili su se utjecajem i interakcijom fenola $u$ antiradikalnoj aktivnosti vrste Aronia melanocarpa. Na grafičkim prikazima ovoga istraživanja primijećena su dva perioda kemijskih reakcija fenolnih komponenti različitih masa. $U$ prvom periodu, od 10 do 30 minuta, uočena je brza redukcija signala DPPH radikala, dok nakon tog vremena gubitak signala sporije je reakcije. Ovakvi rezultati doveli su do pretpostavke o bifaznoj interakciji fenolnih komponenti aronije i DPPH ${ }^{\bullet}$ u kojoj se javljaju „brzi“ i „spori“ antioksidansi. Van den Beg i suradnici ${ }^{20}$ opisali su spori period bifazne reakcije kao vrijeme nastajanja produkta koji sporije reagira sa slobodnim radikalom. To ujedno može označavati period u kojem se mijenja molekulska struktura 
fenolnih komponenti koje predstavljaju jake antioksidativne komponente aronije. U sličnom tipu istraživanja, Broznić i suradniciei ${ }^{21}$ opisali su dva koraka bifazne kinetike, gdje u prvom dolazi do prijenosa vodikovog atoma $s$ antioksidansa na slobodni radikal, a u drugom koraku manje reaktivni formirani radikal $A^{\bullet}$ može ponovno reagirati s ostalim molekulama $\mathrm{DPPH}^{\bullet}$ ili $A^{\bullet} \mathrm{u}$ reakcijama disproporcioniranja radikala. Espin i suradnici ${ }^{22}$ iznijeli su slično objašnjenje, ali stavili su naglasak na kompleksnost reakcija dviju vrsta antioksidansa koje koriste dva različita reakcijska puta. U takvoj interakciji javljaju se dvije konstante kemijske reakcije, $k_{1}$ i $k_{2}$, koje predstavljaju dvije faze nestanka DPPH radikala. Navedene činjenice opravdavaju postojanost „brzih“ i „sporih“ antioksidansa, odnosno postojanost bifazne kinetike prvog reda u uzorcima soka aronije te mješavina soka aronije i crnog vina. Radi jače antioksidativne aktivnosti, u bifaznu kinetiku antioksidansi soka aronije uvode i antioksidanse crnog vina. Pod njihovim utjecajem „brzi“ i „spori“ antioksidansi crnog vina raspodjeljuju se između „brzih“ i „sporih“ antioksidansa soka aronije. Zbog takvog rasporeda, u susretu s radikalom pojavljuju se dvije faze brzine kemijskih reakcija. U prvim fazama javljaju se veće vrijednosti konstanti kinetike, a time i brzine kemijskih reakcija, dok u drugim fazama opadaju vrijednosti konstanti, kao i brzina kemijskih reakcija zbog pojave "sporih" antioksidansa. Za uzorak MIX 1, od svih mješavina soka aronije i crnog vina, dobiven je najveći antioksidacijski kapacitet. To potvrđuje činjenicu kako je spomenuta smjesa pokazatelj najboljeg sinergizma između antioksidansa ovih komponenti. Bifazni model kinetike, nakon primjene antiradikalnih testova, dodatno je potvrdio sinergističku vezu u uzorku MIX 1 pomoću konstanti čije vrijednosti nisu visoke, a značajno se niti ne mijenjaju. Takvi rezultati pokazuju kako se brzina djelovanja antioksidansa previše ne razlikuje u prvoj i drugoj fazi reakcije, što znači da iako postoje „brzi“ i „spori“ antioksidansi u mješavini, brzina njihovog djelovanja u inhibiranju slobodnog radikala gotovo je identična i bez promjena. Odnosno, isti efekt sinergizma antioksidansa uočava se tijekom čitave kemijske reakcije. Upravo zbog toga bi se ovakva smjesa (50\% soka aronije, $50 \%$ crnog vina) pre- poručila za konzumaciju jer bi proces antioksidacije, bez izmjenjivanja perioda stagnacije i rasta brzina, jednako trajao u organizmu sve dok se ne potroše svi antioksidansi u krvi.

\section{ZAKLJUČCI}

Rezultati ovog istraživanja ukazuju na odgovarajući sinergizam uzoraka soka aronije i crnog vina. Oslanjajući se na metodu kvantifikacije, utvrđeno je kako smjesa s 50-postotnim udjelom ovih komponenti pokazuje najveći antioksidacijski kapacitet. Time je dokazano kako dodatak soka aronije u crno vino pospješuje njegovu antioksidativnu aktivnost. Budući da je uzorak soka aronije u objema primijenjenim metodama pokazao najveći antioksidacijski kapacitet, preporučuje ga se koristiti pojedinačno. Na temelju usporedbe eksperimentalnih i matematičkih modelnih podataka, dokazano je da bifazni model prvog reda najbolje opisuje kinetiku kemijskih reakcija između DPPH radikala i antioksidansa uzoraka, dok je najlošije opisuje model nultog reda. Potvrđeno je kako se kinetička reakcija ostvaruje u dvjema fazama (brzinama), odnosno prisustvom „brzih“ i „sporih“ antioksidanasa. Kako bi se mogle identificirati komponente uzoraka koje predstavljaju „brze“ i „spore“ antioksidanse, potrebna su dodatna istraživanja koja uključuju mehanizam kemijskih reakcija zbog kojeg dolazi do sinergizma antioksidansa iz soka aronije i crnog vina.

\section{Zahvala}

Istraživanje je provedeno u okviru znanstvenoistraživačkog projekta Uniri-biomed-18-155-1304 financiranog od Sveučilišta u Rijeci.

Izjava o sukobu interesa: Autori izjavljuju da ne postoji sukob interesa.

\section{LITERATURA}

1. Jurikova T, Mlcek J, Skrovankova S, Sumczynski D, Sochor J, Hlavacova I et al. Fruits of Black Chokeberry Aronia melanocarpa in the Prevention of Chronic Diseases. Molecules 2017;22:1-24.

2. Denev P, Číž M, Kratchanova M, Blazheva D. Black chokeberry (Aronia melanocarpa) polyphenols reveal different antioxidant, antimicrobial and neutrophil-modulating activities. Food Chem 2019;284:108-117.

3. Kokotkiewicz A, Jaremicz Z, Luczkiewicz M. Aronia Plants: A Review of Traditional Use, Biological Activities, and Perspectives for Modern Medicine. J Med Food 2010;13:255-69. 
4. Bräunlich M, Økstad OA, Slimestad R, Wangensteen $\mathrm{H}$, Malterud KE, Barsett H. Effects of Aronia melanocarpa Constituents on Biofilm Formation of Escherichia coli and Bacillus cereus. Molecules 2013;18:14989-99.

5. Daskalova E, Delcheva S, Topolov M, Dimitrova S, Uzunovac $Y$, Valcheva-Kuzmanova $S$ et al. Aronia melanocarpa (Michx.) Elliot fruit juice reveals neuroprotective effect and improves cognitive and locomotor functions of aged rats. Food Chem Toxicol 2019;132:1-6.

6. Kędzierska M, Malinowska J, Kontek B, KołodziejczykCzepas B, Czernek U, Potemski P et al. Chemotherapy modulates the biological activity of breast cancer patients plasma: the protective properties of black chokeberry extract. Food Chem Toxicol 2013;53:126-32.

7. Alpeza I. Temelji kemijskog sastava vina. Glasnik Zaštite bilja 2008;31:143-50.

8. Snopek L, Mlcek J, Sochorova L, Baron M, Hlavacova I, Jurikova T et al. Contribution of Red Wine Consumption to Human Health Protection. Molecules 2018;23:1-16.

9. Toth A, Sandor B, Papp J, Rabai M, Botor D, Horvath Zs et al. Moderate red wine consumption improves hemorheological parameters in healthy volunteers. Clin Hemorheol Microcirc 2014;56:13-23.

10. Sánchez MC, Ribeiro-Vidal H, Esteban-Fernández A, Bartolomé B, Figuero E, Moreno-Arribas MV et al. Antimicrobial activity of red wine and oenological extracts against periodontal pathogens in a validated oral biofilm model. BMC Complement Altern Med 2019;19:145-57.

11. Fernandes I, Pérez-Gregorio R, Soares $S$, Mateus $N$, de Freitas V. Wine Flavonoids in Health and Disease Prevention. Molecules 2017;22:292-322.

12. Oxidative Stress and Diseases [Internet]. London: IntechOpen, Inc. 2012 [cited 2012 Jul 19]; Available from: https://www.intechopen.com/books/oxidative-stressand-diseases.

13. Kedare Sagar B, Singh RP. Genesis and development of DPPH method of antioxidant assay. J Food Sci Technol 2011;48:412-22.
14. Jakobek L, Šeruga Marijan, Krivak P. The influence of interactions among phenolic compounds on the antiradical activity of chokeberries (Aronia melanocarpa). Int. J. Food Sci Nutr 2011;62:345-7.

15. Pinelo M, Manzocco L, Nuñez MJ, Nicoli MC. Interaction among phenols in food fortification: negative synergism on antioxidant capacity. J Agric Food Chem 2004;52: 1177-80.

16. Hidalgo M, Sánchez-Moreno C, de Pascual TS. Flavonoidflavonoid interaction and its effect on their antioxidant activity. Food Chem 2010;121:691-6.

17. Tolić MT, Landeka Jurčević I, Panjkota Krbavčić I, Marković K, Vahčić N. Phenolic Content, Antioxidant Capacity and Quality of Chokeberry (Aronia melanocarpa) Products. Food Technol Biotechnol 2015;53:171-9.

18. Stratil P, Kubáň V, Fojtová J. Comparison of the Phenolic Content and Total Antioxidant Activity in Wines as Determined by Spectrophotometric Methods. Czech J Food Sci 2008;26:242-53.

19. Jakobek L, Šeruga M, Krivak P. The influence of interactions among phenolic compounds on the antiradical activity of chokeberries (Aronia melanocarpa). Int J Food Sci Nutr 2011;62:345-8.

20. Van den Berg R, Haenen GRMM, Van den Berg H, Bast A. Applicability of an improved Trolox equivalent antioxidant capacity (TEAC) assay for evaluation of antioxidant capacity measurements of mixtures. Food Chem 1999; 66:511-17.

21. Broznić $D$, Čanadi Jurešić $G$, Milin Č. Involvement of $\alpha$-, $\gamma$ - and $\delta$-Tocopherol Isomers from Pumpkin (Cucurbita pepo L.) Seed Oil or Oil Mixtures in the Biphasic DPPH' Disappearance Kinetics. Food Technol. Biotechnol 2016; 54:200-10.

22. Espin JC, Soler-Rivas C, Wichers HJ. Characterization of the total free radical scavenger capacity of vegetable oils and oil fractions using 2,2-diphenyl-1-picrylhydrazyl radical. J Agric Food Chem 2000;48:648-56. 